\title{
Penggunaan Model Pembelajaran Two Stay Two Stray Sebagai Upaya Meningkatkan Prestasi Belajar PPKn
}

\section{Wayan Sudiarsana*}

SMP Negeri 1 Blahbatuh

\section{A R T I C L E IN F O}

Article history:

Received 12 February 2020

Received in revised form 18 March 2020

Accepted 30 April 2020

Available online 27 May 2020

Kata Kunci:

Model Pembelajaran Two Stay Two Stray, Prestasi

Belajar PPKn

Keywords:

Two Stay Two Stray

Learning Model, Learning

Achievement PPKn

\begin{abstract}
A B S T R A K
Penelitian dilaksanakan di SMP Negeri 1 Blahbatuh di Kelas VII $C$ yang kemampuan siswanya dalam mata pelajara PPKn masih rendah. Tujuan penulisan penelitian tindakan kelas ini adalah untuk mengetahui apakah Model Pembelajaran Two Stay Two Stray dapat meningkatkan prestasi belajar siswa. Metode pengumpulan datanya adalah tes prestasi belajar. Metode analisis datanya adalah deskriptif. Hasil yang diperoleh dari penelitian ini adalah Model Pembelajaran Two Stay Two Stray dapat meningkatkan prestasi belajar siswa. Ini terbukti dari hasil yang diperoleh pada awalnya 68,05 , pada siklus I menjadi 73.33 dan pada siklus II menjadi 80,69. Kesimpulan yang diperoleh dari penelitian ini adalah Model Pembelajaran Two Stay Two Stray dapat meningkatkan prestasi belajar PPKn siswa kelas VII C SMP Negeri 1 Blahbatuh Semester II Tahun Pelajaran 2017/2018.
\end{abstract}

\section{A B S T R A C T}

This research was conducted at SMP Negeri 1 Blahbatuh in Class VII C where the students' ability in PPKn subjects was still low. The purpose of writing this class action research is to find out whether the Two Stay Two Stray Learning Model can improve student achievement. The data collection method is a learning achievement test. The data analysis method is descriptive. The results obtained from this study are the Two Stay Two Stray Learning Model can improve student learning achievement. This is evident from the results obtained initially at 68.05, in the first cycle to 73.33 and in the second cycle to 80.69. The conclusion obtained from this study is that the Two Stay Two Stray Learning Model can improve the learning achievement of PPKn students of class VII C of SMP Negeri 1 Blahbatuh Semester II in the Academic Year 2017/2018. 


\section{Pendahuluan}

Pendidikan mempunyai peranan yang sangat penting dalam perkembangan seluruh aspek keperibadian dan kehidupan manusia. Menurut UU. No. 20 tahun 2003 tentang Pendidikan disebutkan Pendidikan nasional berfungsi mengembangkan kemampuan dan membentuk watak serta peradaban bangsa yang bermartabat dalam rangka mencerdaskan kehidupan bangsa, bertujuan untuk berkembangnya potensi peserta didik agar menjadi manusia yang beriman dan bertakwa kepada Tuhan Yang Maha Esa, berakhlak mulia, sehat, berilmu, cakap, kreatif, mandiri, dan menjadi warga negara yang demokratis serta bertanggung jawab.

UU No. 20 tahun 2003 tentang Sistem Pendidikan Nasional menegaskan bahwa pendidikan adalah usaha sadar dan terencana untuk mewujudkan suasana belajar dan proses pembelajaran agar peserta didik secara aktif mengembangkan potensi dirinya untuk memiliki kekuatan spiritual keagamaan, penyerahan diri, kepribadian, kecerdasan, akhlak mulia serta keterampilan yang diperlukan dirinya, masyarakat, bangsa dan negara. Usaha sadar yang disebutkan tentu sebagai seorang guru harus secara sadar mempersiapkan segala sesuatu seperti membuat perencanaan yang benar dan baik sebelum mengajar.

Pendidikan bagian yang sangat penting dalam proses pembangunan suatu bangsa dan negara, karena tanpa didukungnya pendidikan tidak mungkin pembangunan suatu bangsa dan negara dapat berkembang dengan baik. Kita dapat melihat contohnya yaitu perkembangan antara desa dengan kota, dimana kota bisa dianggap lebih berkembang dari pada desa dikarenakan sistem pembangunan yang dipimpin oleh orang-orang terpelajar. Pendidikan itu sebenarnya harus didapatkan oleh setiap lapisan masyarakat agar pembangunan suatu bangsa dan negara itu dapat berjalan dengan baik. Hal tersebut juga terlihat dalam UUD 1945 pasal 31 yang menyatakan bahwa setiap warga negara berhak mendapatkan pendidikan (Amandemen UUD 1945, Bab XIII tentang Pendidikan dan Kebudayaan). Pernyataan dalam pasal 31 itu sekaligus merupakan landasan dan jaminan bagi setiap warga negara Indonesia untuk memperoleh pendidikan tanpa membedakan suku, agama, dan golongan. Hasil pendidikan yang diperoleh setiap warga negara diharapkan dapat meningkatkan kualitas sumber daya manusia Indonesia secara sendiri-sendiri atau keseluruhan di masa kini dan mendatang. Sumber daya manusia Indonesia yang berkualitas tersebut memiliki ciri sebagaimana tersebut dalam tujuan pendidikan nasional yaitu: "Pendidikan nasional berfungsi mengembangkan kemampuan dan membentuk watak serta peradaban bangsa yang bermartabat dalam rangka mencerdaskan kehidupan bangsa, bertujuan untuk berkembangnya potensi peserta didik agar menjadi manusia yang beriman dan bertakwa kepada Tuhan Yang Maha Esa, berakhlak mulia, sehat, berilmu, cakap, kreatif, mandiri, dan menjadi warga negara yang demokratis serta bertanggung jawab.". (UUD RI Sistem Pendidikan Nasional: 2003, 2) (Sirait, 2016).

Pendidikan merupakan kegiatan terencana yang berlangsung sepanjang hidup dan menjadi kebutuhan bagi manusia. Pendidikan tidak hanya berlangsung di sekolah, akan tetapi dapat juga berlangsung di dalam keluarga dan masyarakat. Oleh karena itu, pendidikan menjadi tanggung jawab bersama antara keluarga, masyarakat, dan juga pemerintah. Pendidikan memegang peranan penting bagi kehidupan manusia. Tanpa pendidikan manusia akan sulit berkembang atau bahkan tidak berkembang. Dengan demikian, pendidikan harus benarbenar diarahkan agar menghasilkan manusia yang berkembang dan berkualitas serta mampu bersaing, di samping memiliki akhlak dan moral yang baik.

Keberhasilan belajar peserta didik dipengaruhi oleh beberapa faktor, dapat berasal dari diri peserta didik sendiri maupun dari guru sebagai pendidik. Faktor yang berasal dari guru di antaranya kemampuan dalam merancang pembelajaran yang mampu menumbuhkan motivasi belajar peserta didik, menciptakan suasana belajar yang menarik dan menyenangkan. Namun pada kenyataannya, peserta didik masih menganggap matematika sebagai mata pelajaran yang menakutkan sehingga susah untuk dipahami. Hal ini terjadi karena pendidik belum mampu mengemas pembelajaran matematika menjadi lebih menyenangkan yang mampu menarik perhatian peserta didik. Sehingga membuat prestasi belajar peserta didik tidak sesuai dengan yang diharapkan.

Proses pembelajaran saat ini masih cenderung menempatkan guru sebagai pusat pembelajaran atau satu-satunya sumber belajar. Guru hanya sekedar memberikan pengetahuan kepada siswa. Siswa tidak diberikan kesempatan untuk membangun sendiri pengetahuan yang dimilikinya. Tentunya keadaan seperti itu berpengaruh pada hasil belajar siswa. Untuk itu perlu adanya perubahan dalam proses pembelajaran dimana dalam proses pembelajaran lebih diarahkan pada keaktifan siswa. Guru dapat memberikan kesempatan kepada siswa untuk membangun sendiri pengetahuan mereka serta guru bukan satu-satunya sebagai sumber belajar. Oleh karena itu, guru diharapkan mampu memilih model pembelajaran yang sesuai dengan materi pembelajaran agar diperoleh hasil belajar siswa yang baik (Ayuwanti, 2016). 
Berbagai laporan mengungkapkan bahwa prestasi belajar (academic achievement) peserta didik Indonesia kurang optimal. Laporan-laporan tersebut antara lain oleh The International Association for the Evaluation of Educational Achievement (IEA) Tahun 2011. IEA merupakan salah satu lembaga Internasional independen, melakukan penelitian dan studi dalam skala besar mengukur perbandingan prestasi dan aspek-aspek lain pendidikan di 64 negara di dunia sebagai peserta. Dari hasil pengukuran kemampuan bidang IPA dan matematika Internasional, pelajar SMP Indonesia berada pada urutan 38 dari 39 negara yang disurvei (IEA, 2011), sedangkan hasil pengukuran Trends in International Mathematics and Science Study (TIMSS) Tahun 2011, kemampuan matematika pelajar SMP Indonesia juga berada pada urutan 34 dari 38 negara, sedangkan kemampuan pelajar Indonesia pada bidang IPA berada di urutan ke 32 dari 38 negara yang disurvei (TIMSS, 2011).

Kualitas pendidikan Indonesia seperti yang dilaporkan oleh The International Association for the Evaluation of Educational Achievement (IEA) dan Trends in International Mathematics and Science Study (TIMSS), perlu dicermati dan ditindaklanjuti. Berdasarkan pralapangan diketahui bahwa SMA Negeri 1 Lawang Kabupaten Malang: skor rata-rata nilai Ujian Nasional (UN) lima mata pelajaran perolehan nilai dengan rentang skor 8.6 sampai dengan 10 hanya diperoleh oleh 26 dari 412 peserta didik yang ikut dan dinyatkan lulus UN 2012. Hal ini berarti bahwa hanya 6.28\% lulus dengan prestasi belajar yang baik, sementara 274 peserta didik (66.52\%) berada pada posisi sedang dan 112 peserta didik (27.20\%) berada pada posisi rendah. Lebih lanjut, penelusuran literatur, cukup banyak penelitian yang mencoba mengungkapkan kasus menyontek. Penelitian Rittman (1996); Bogle (2000); dan Turrens, dkk., (2002) mencoba mengungkap perilaku menyontek dengan angket sebagai alat instrumenasinya. Penelitian Thorpe, dkk., (1999) perilaku menyontek terjadi karena nilai pelajar rendah karena kemampuannya memang rendah, ia memiliki hasrat untuk mendapatkan nilai belajar yang lebih tinggi (Yuzarion, 2017).

Perlu diingat bahwa untuk bisa melakukan sesuatu agar berhasil haruslah giat mengupayakannya. Untuk hal tersebut dituntut keuletan, keilmuan, kemampuan, kecekatan dalam merencanakan dan mengaplikasikan apa yang diketahui sesuai keilmuan yang dikuasai.

Seperti telah dijelaskan di paragraf sebelumnya bahwa pendidikan adalah usaha sadar dan terencana untuk mewujudkan suasana belajar dan proses pembelajaran agar peserta didik secara aktif dapat mengembangkan potensi dirinya untuk memiliki kekuatan spiritual keagamaan, pengendalian diri, kepribadian, kecerdasan, akhlak mulia, serta keterampilan yang diperlukan dirinya, masyarakat, bangsa dan negara. Untuk dapat mewujudkan tujuan tersebut, dalam rangka meningkatkan mutu pendidikan diperlukan berbagai upaya aktif dari pendidik untuk mewujudkan pembelajaran yang efektif dan efisien.Proses pembelajaran di kelas akanberhasil jikadalam pelaksanaannya guru memahami dengan baik peran, fungsi dan kegunaan mata pelajaran yang diajarnya. Disamping mengetahui peran, fungsi dan kegunaan mata pelajaran, guru juga diharapkan mampu menerapkan berbagai metode ajar sehingga paradigma pengajaran dapat dirubah menjadi paradigma pembelajaran.

Untuk mampu melakukan semua hal yang diharapkan oleh pemerintah, maka sebagai seorang guru harus memiliki keterampilan dalam melaksanakan pembelajaran.Wardani dan Siti Julaeha menjelaskan tujuh syarat keterampilan yang mesti dikuasai guru dalam melaksanakan pembelajaran untuk disebut profesional, yaitu: 1) keterampilan bertanya, 2) keterampilan memberi penguatan, 3) keterampilan mengadakan variasi, 4) keterampilan menjelaskan, 5) keterampilan membuka dan menutup pelajaran, 6) keterampilan membimbing diskusi, dan 7) keterampilan mengelola kelas. Keterampilan-keterampilan ini berhubungan dengan kemampuan guru untuk menguasai dasar-dasar pengetahuan yang dapat memudahkan mereka untuk melakukan persiapan dan pelaksanaan proses pembelajaran untuk memberikan dukungan terhadap cara berpikir siswa yang kreatif dan imajinatif (Modul IDIK 4307: 1-30).

Rendahnya prestasi belajar siswa bisa saja disebabkan oleh rendahnya kemauan guru untuk menerapkan model dan strategi pembelajaran yang benar yang bisa membuat siswa aktif dalam belajar.Masih banyak guru lebih cenderung berperan sebagai penyampai materi ajar ketimbang sebagai seorang guru sejati yang seharusnya bertugas sebagai pendidik dan pengajar.Hal tersebut terjadi akibat rendahnyakemauan guru menyiapkan bahan yang lebih baik, termasuk kemauan guru itu sendiri untuk menerapkan metode-metode ajar yang lebih konstruktivis.Selain itu, guru kurang berkeinginan untuk mengembangkan keterampilan mengajar yang dapat menarik perhatian siswa dan merangsang siswa lebih aktif dalam belajar.

Pengamatan peneliti terhadap siswa kelas VII C pada semester II tahun pelajaran 2017/2018 ternyata masih sangat rendah dengan pencapaian rata-rata 68,05. Hasil ini jauh di bawah KKM mata pelajaran PPKN di sekolah ini yaitu 75,00. Adanya kesenjangan antara harapan-harapan yang telah disampaikan dengan kenyataan lapangan sangat jauh berbeda, dalam upaya memperbaiki mutu pendidikan yaitu pada mata pelajaran PPKN, sangat perlu dilakukan perbaikan cara pembelajaran. Salah satunya adalah perbaikan pembelajaran dengan menggunakan Model Pembelajaran Two Stay Two Stray. Metode ini berpijak pada dasar pemikiran bahwa semua manusia dilahirkan dengan rasa ingin tahu yang 
tidak pernah terpuaskan, serta mempunyai alat-alat yang diperlukan untuk memuaskannya.Pembelajaran dengan menerapkan Model Pembelajaran Two Stay Two Stray sebagai salah satu model, strategi, dan pendekatan pembelajaran khususnya menyangkut keterampilan guru dalam mematangkan materi lewat tanya jawab. Dengan cara tersebut penelitian ini mampu menciptakan suasana pembelajaran yang efektif dan menggairahkan. Semua penjelasan di atas diupayakan sebagai solusi dalam mengatasi masalah prestasi belajar siswa yang masih rendah.

\section{Metode}

Dalam melaksanakan Penelitian Tindakan Kelas, langkah-langkah atau prosedur PTK didasarkan pada model rancangan PTK dari para ahli. Selama ini dikenal berbagai model PTK, namun pada dasarnya terdapat empat tahap yang harus dilalui yaitu (1) perencanan (planning), (2) pelaksanaan (acting), (3) pengamatan (observing), dan (4) refleksi (reflecting). Keempat tahap tersebut merupakan satu siklus dan akan dapat berlanjut kepada siklus kedua, siklus ketiga dan seterusnya sesuai dengan apa yang diinginkan dalam penelitian. Untuk penelitian ini penulis memilih rancangan penelitian tindakan yang disampaikan depdiknas seperti terlihat pada gambar berikut.

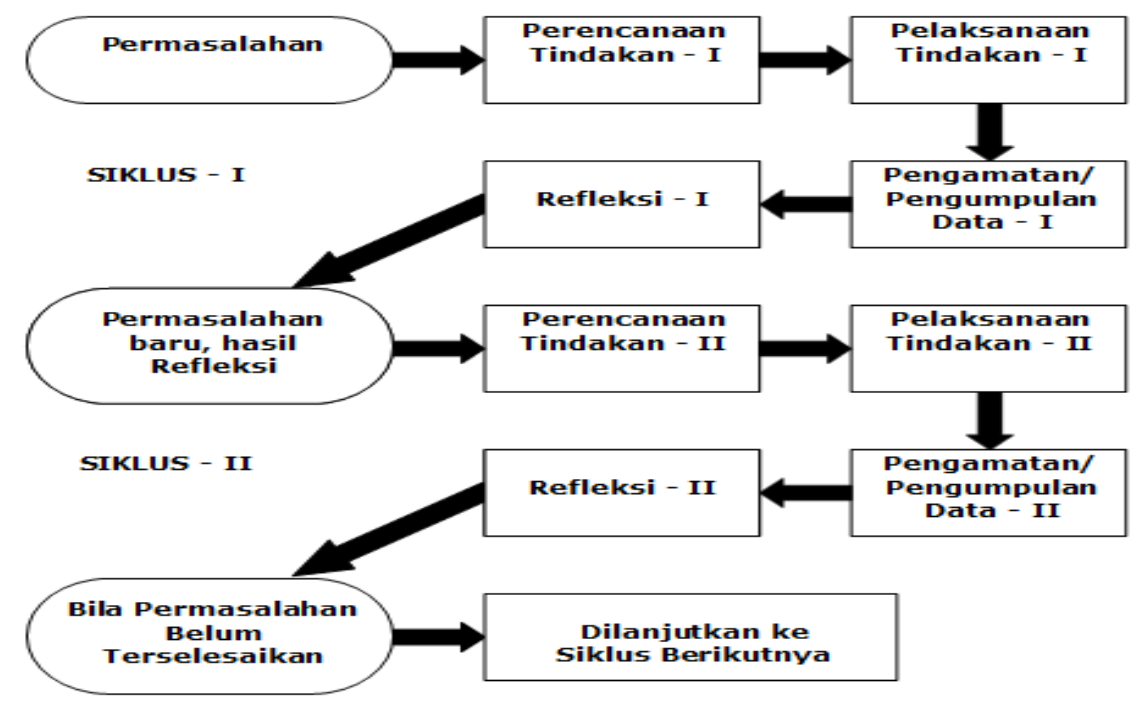

Gambar 1. Siklus PTK (Depdiknas, 2011: 12)

Dimulai dengan melihat adanya masalah di lapangan.Dengan adanya masalah di lapangan maka peneliti mulai membuat perencanaan I dan selanjutnya melaksanakannya, mengamati atau mengumpulkan data, melakukan refleksi I.

Setelah ada permasalahan baru hasil refleksi lalu dibuat perencanaan siklus II, dilanjutnya dengan pelaksanaannya, diamati atau diobservasi dan direfleksi dan apabila permasalahan belum selesai dilanjutkan dengan siklus berikutnya. Pengumpulan data dalam penelitian ini menggunakan tes prestasi belajar. Tes prestasi belajar berupa tes soal isian maupun esay. Untuk menganalisis data hasil penelitian ini digunakan metode deskriptif. Untuk data kuantitatif dianalisis dengan mencari mean, median, modus, membuat interval kelas dan melakukan penyajian dalam bentuk tabel dan grafik. Indikator keberhasilan penelitian yang diusulkan dalam penelitian ini pada siklus I dan II mencapai nilai rata-rata 75,00 dengan ketuntasan belajar 85\%. dengan KKM yang ditetapkan untuk mata pelarajan PPKn pada SMP Negeri 1 Blahbatuh adalah 75.

\section{Hasil dan Pembahasan}

Pembelajaran dengan mengupayakan metode yang baru dan konsekuen dalam pelaksanaannya akan mampu membantu peserta didik untuk meningkatkan prestasinya. Model Pembelajaran Two Stay Two Stray sangat cocok untuk dicoba mengingat metode tersebut merupakan sesuatu yang gampang untuk dikerjakan.

Tujuan Model Pembelajaran Two Stay Two Stray Dalam model pembelajaran ini siswa dihadapkan pada kegiatan mendengarkan apa yang diutarakan oleh temannya ketika sedang bertamu, yang secara tidak langsung siswa akan dibawa untuk menyimak apa yang diutarakan oleh anggota kelompok yang 
menjadi tuan rumah tersebut. Dalam proses ini, akan terjadi kegiatan menyimak materi pada siswa. Dalam model pembelajaran kooperatif Two Stay Two Stray ini memiliki tujuan yang sama dengan pendekatan pembelajaran kooperatif yang telah di bahas sebelumnya. Siswa di ajak untuk bergotong royong dalam menemukan suatu konsep. Penggunaan model pembelajaran kooperatif Two Stay Two Stray akan mengarahkan siswa untuk aktif, baik dalam berdiskusi, tanya jawab, mencari jawaban, menjelaskan dan juga menyimak materi yang dijelaskan oleh teman.

Kelebihan dari model pembelajaran Two Stay Two Stray adalah a) dapat diterapkan pada semua kelas/tingkatan, b) kecenderungan belajar siswa menjadi lebih bermakna, c) lebih berorientasi pada keaktifan, d) diharapkan siswa akan berani mengungkapkan pendapatnya, e) menambah kekompakan dan rasa percaya diri siswa, f) kemampuan berbicara siswa dapat ditingkatkan, dan g) membantu meningkatkan minat dan prestasi belajar.

Pada tes awal sebelum penelitian menunjukan perolehan nilai rata rata kelas hasil belajar PPKN masih sangat rendah, yaitu dengan perolehan skor nilai secara klasikal yaitu 2450 dan rata rata kelas 68,05 , dimana siswa yang mencapai persentase ketuntasan belajar $36,11 \%$, dan yang tidak mencapai ketuntasan adalah 63,88\%, dengan tuntutan KKM untuk mata pelajaran PPKN kelas VII C SMP Negeri 1 Blahbatuh adalah dengan nilai 75 .

Upaya untuk mengatasi rendahnya prestasi belajar PPKN siswa di atas, dilakukan dengan menerapkan model pembelajaran Two Stay Two Stray. Hasil dari penelitian yang telah dilakukan adalah: pada siklus I sudah diupayakan untuk perbaikan pembelajaran untuk meningkatkan hasil belajar PPKN dengan menggunakan Model Pembelajaran Two Stay Two Stray. Peneliti telah giat melakukan kegiatan yang susuai dengan kebenaran teori yang ada sehingga peneliti memperoleh hasil yang lebih baik dari proses awal, yaitu dengan rata rata nilai 73,33 dari jumlah nilai 2640 seluruh siswa di kelas VII C SMP Negeri 1 Blahbatuh dan prosentase ketuntasan belajarnya adalah $75 \%$ yang tidak tuntas adalah $25 \%$. Hasil ini belum maksimal, karena belum mecapai indikator keberhasilan penelitian yang mencanangkan dengan minimal prosentase ketuntasan belajar $85 \%$.

Berdasarkan pengalaman dan hasil yang diperoleh selama kegiatan pembelajaran, menjadi pertimbangan yang perlu diperhatikan yakni pendekatan dan metode pembelajaran seperti yang telah dilaksanakan sangat cocok dimanfaatkan pada pembelajaran ini terbukti dari peningkatan hasil pembelajaran yang sangat singnifikan dari 73,33 pada siklus I menjadi 80,69 pada siklus II.

Hasil penelitian ini sejalan dengan penelitain yang telah dilakukan oleh Manik dan Abdul (2016) berjudul Penerapan Model Two Stay Two Stray Berbantuan Multimedia Untuk Meningkatkan Aktivitas dan Hasil Belajar IPS. Hasil penelitian adalah: (1) penerapan model pembelajaran Two Stay Two Stray berbantuan multimedia dalam pembelajaran IPS dapat meningkatkan aktivitas belajar siswa: pada kondisi awal siswa yang aktif hanya 55,56 \%, pada siklus I meningkat menjadi 59,10\%, dan pada siklus II menjadi 85,50\%. (2) pembelajaran IPS dengan penerapan model kooperatif Two Stay Two Stray berbantuan multimedia dapat meningkatkan hasil belajar siswa: dari kondisi awal rata-rata hasil belajar siswa 68,61, meningkat pada siklus I menjadi 71,94 dan pada siklus II menjadi 82,10. Dengan demikian ketuntasan klasikal meningkat dari kondisi awal 58,33\%, pada siklus I menjadi $77,78 \%$, dan pada siklus II menjadi $100 \%$.

Penelitian yang dilakukan oleh Suhaida dan Jayanti (2017) berjudul Penerapan Metode Kooperatif Two Stay Two Stray (TSTS) Pada Pembelajaran PKN Untuk Meningkatkan Hasil Belajar Siswa. Hasil penelitian menunjukkan bahwa, secara umum penerapan metode Kooperatif Teknik TSTS di kelas VIII dilakukan dengan baik. Secara khusus: bahwa perencanaan dilakukan terlebih dulu oleh guru PKn dan mengacu kepada kurikulum KTSP, pelaksanaan Metode Kooperatif Teknik TSTS dilakukan dalam dua siklus dan pelaksanaan berjalan baik dan lancar, hasil belajar siswa di kelas VIII sebelum menggunakan Metode Kooperatif Teknik TSTS (pra-siklus) hanya mencapai 36\%, nilai rata-rata 56, setelah guru PKn menerapkan Metode Kooperatif Teknik TSTS hasil belajar siswa meningkat pada (siklus I) 67\% nilai ratarata 69 , selanjutnya pada (siklus II) hasil belajar siswa mengalami peningkatan sebanyak $86 \%$ dengan nilai rata-rata 78.

\section{Simpulan Dan Saran}

Penelitian Simpulan yang dapat disampaikan berdasarkan semua hasil analisis data yang telah dilakukan dengan melihat hubungan rumusan masalah, tujuan penelitian, hipotesis tindakan dan semua hasil pembahasan adalah sebagai berikut:

1. Fokus pembahasan dari penelitian ini adalah untuk membuktikan apakah Model Pembelajaran Two Stay Two Stray dapat meningkatkan prestasi belajar PPKn. Dari hasi analisis yang telah dilakukan yang dilanjutkan dengan pembahasan dapat disampaikan bahwa peningkatan hasil belajar telah dapat 
diupayakan. Dari data awal yang rata-rata baru mencapai 68,05 dan jauh dari kriteria ketuntasan minimal pada mata pelajaran ini, pada siklus I sudah dapat ditingkatkan menjadi 73,33 dan pada siklus II sudah mencapai rata-rata 80,69. Siswa yang pada awalnya kemampuannya masih sangat rendah dimana hanya ada 13 yang tuntas, pada siklus I sudah dapat ditingkatkan yaitu ada 27 siswa yang sudah tuntas dan pada siklus II sudah 35 yang tuntas. Dari hasil awal ada 23 siswa yang harus diremidi sedangkan pada siklus II ada 1 siswa yang mesti diremidi.

2. Dari uraian fakta-fakta di atas yang dibarengi dengan penyajian data hasil observasi baik siklus I maupun siklus II yang disampaikan pada Bab IV telah dapat dibuktikan bahwa Model Pembelajaran Two Stay Two Stray dapat meningkatkan kemampuan siswa dalam belajar. Dengan hasil tersebut dapat dibuktikan bahwa rumusan masalah dan tujuan penelitian telah tercapai dan hipotesis yang diajukan sudah dapat diterima. Untuk hal tersebut selanjutnya perlu disampaikan saran.

Berdasarkan temuan yang sudah disimpulan dari hasil penelitian, dalam upaya mencapai tujuan pembelajaran, dapat disampaikan saran-saran sebagai berikut.

1. Bagi guru kelas, apabila mau melaksanakan proses pembelajaran penggunaan metode yang telah diterapkan ini semestinya menjadi pilihan dari beberapa metode yang ada mengingat metode ini telah terbukti dapat meningkatkan kualitas pembelajaran.

2. Bagi peneliti lain, walaupun penelitian ini sudah dapat membuktikan efek utama dari Model Pembelajaran Two Stay Two Stray dalam meningkatkan prestasi belajar, sudah pasti dalam penelitian ini masih ada hal-hal yang belum sempurna dilakukan, oleh karenanya kepada peneliti lain yang berminat meneliti topik yang sama untuk meneliti bagian-bagian yang tidak sempat diteliti.

3. Bagi pengembang pendidikan, selanjutnya untuk adanya penguatan-penguatan, diharapkan bagi peneliti lain untuk melakukan penelitian lanjutan guna memverifikasi data hasil penelitian ini.

\section{Daftar Rujukan}

Ayuwanti, Irma . 2016. Meningkatkan Aktivitas Dan Hasil Belajar Matematika Menggunakan Model Pembelajaran Kooperatif Tipe Group Investigation Di Smk Tuma'ninah Yasin Metro . Jurnal SAP Vol. 1 No. 2 Desember 2016.

Dahar, Ratna Wilis. 1989. Teori-Teori Belajar. Jakarta: Penerbit Erlangga.

Depdiknas. 2011. Membimbing Guru dalam Penelitian Tindakan Kelas. Jakarta: Pusat Pengembangan Tenaga Kependidikan, Badan Pengembangan Sumber Daya Manusia Pendidikan dan Penjaminan Mutu Pendidikan.

Fernandes, H.J.X. 1984. Testing and Measurement. Jakarta. National Education Planning, Evaluation and Curriculum Development.

Fraenkel, Jack R. and Norman E. Wallen. 1993. How to Design and Evaluate Research in Education. Second Edition. New York: McGraw-Hill, Inc.

Gagne, Robert M. 1977. The Conditions of Learning. Third Edition. New York: Holt, Reinhart and Winston.

Gay, L. R. 1987. Educational Research: Competencies for Analysis and Application. Seventh Edition. Columbus, Ohio: Merrill Publishing Company.

Hamalik, Oemar. 2002. Psikologi Belajar dan Mengajar. Bandung: Sinar Baru.

Herrhyanto, Nar dan Hamid, Akib. 2006. Statistika Dasar. Jakarta: Universitas Terbuka.

Hilke, Eileen Veronica. 1998. Fastback Cooperative Learning. New York: McGraw-Hill, Inc.

Lie, Anita. 2002. Cooperative Learning: Mempraktikkan Cooperative Learning di Ruang-Ruang Kelas. Jakarta: PT Gramedia Widiasarana Indonesia.

Manik, Kardi dan Abdul Gafur. 2016. Penerapan Model Two Stay Two Stray Berbantuan Multimedia Untuk Meningkatkan Aktivitas dan Hasil Belajar IPS. Harmoni Sosial: Jurnal pendidikan IPS Volume 3 Nomor 1 . 
Miles, Matthew, B. Dan A. Michael Hubberman. 1992. Analisis Data Kualitatif. Terjemahan Tjetjep Roheadi Rohidi. Jakarta: Penerbit Universitas Indonesia.

Modern Educators and Lexicographers. 1939. Webster's New American Detionary. New York: 140 Broadway, Books, Inc.

Nur, Mohamad et al. 2001. Teori Belajar. Surabaya: University Press.

Peraturan Menteri Pendidikan Nasional No. 41 Tahun 2007 Tanggal 23 November 2007. Jakarta: Depdiknas.

Popham, W. James dan Eva L. Baker. 1984. Bagaimana Mengajar Secara Sistematis. Diterjemahkan Oleh R.H. Dj. Sinurat et al. Yogyakarta: Kanisius.

Sirait, Erlando Doni . 2016. Pengaruh Minat Belajar Terhadap Prestasi Belajar Matematika . Jurnal Formatif 6(1): 35-43, 2016

Suhaida, Dada dan Nur Fitri Jayanti. 2017. Penerapan Metode Kooperatif Two Stay Two Stray (TSTS) Pada Pembelajaran PKN Untuk Meningkatkan Hasil Belajar Siswa. Jurnal Sosial Horizon: Jurnal Pendidikan Sosial Vol. 4, No. 1, Juni 2017.

Yuzarion . 2017. Faktor Yang Mempengaruhi Prestasi Belajar Peserta Didik . Ilmu Pendidikan, Volume 2 Nomor 1, Juni 2017. 